ORIGINAL ARTICLE

\title{
Accidental breaches of the doping regulations in sport: is there a need to improve the education of sportspeople?
}

\author{
S J Somerville, M Lewis
}

Br J Sports Med 2005;39:512-516. doi: 10.1136/bjsm.2004.013839

See end of article for authors' affiliations

.....................

Correspondence to: Dr Somerville, The John Kelso Practice, Park Medical Centre, Ball Hay Road, Leek ST13 6QR, UK; simon@somerville22.

freeserve.co.uk

Accepted 22 August 2004
Objectives: To identify educational needs of elite sportspeople with respect to the doping laws.

Methods: A questionnaire survey of 196 Olympic level sportspeople from the fields of athletics, cycling, rowing, and sailing. The questionnaire addressed the date and source of the last doping educational update, the usefulness of current resources, sources of help, and possible ways of improving the system. The questionnaire also sought to estimate the use of nutritional supplements in these sports.

Results: Seventy four (38\%) athletes responded to the questionnaire. Over $90 \%$ of responders had received a doping educational update in the last six months, and most agreed with the statement "I have received the information I need to avoid getting into trouble with the doping laws". Despite this, more than half of responders agreed with the statements "I should receive reminders more often" and "The authorities should do more to educate sportspeople". In addition, there were four people who admitted taking a banned substance by accident. Forty one (55\%) reported taking supplements. The team doctor was the most popular source if information on a substance or product was required, with $62 \%$ and $66 \%$ of subjects stating that they would contact their team doctor when based in the United Kingdom and abroad respectively. The UK Sports website was often suggested in relation to ways of improving knowledge.

Conclusions: There is a need to alter the educational process, particularly with respect to contingency planning for minor illness. The use of internet based resources for up to date information about banned substances needs to be promoted, and access to the internet improved. The educational needs of team doctors with respect to the doping laws need to be assessed.
$\mathrm{T}$ World Anti-Doping Agency (WADA) defines in the World Anti-Doping Code acts that constitute a code violation. These include "the presence of a prohibited substance or its metabolite or markers in an athlete's bodily specimen". ${ }^{1}$ The World Anti-Doping Code lists these prohibited substances. ${ }^{2}$ A doping offence occurs when a sportsperson tests positive for a banned substance, regardless of how it got there.

Although there are undoubtedly sportspeople who do deliberately cheat by taking banned drugs, there are also a number who take something purely by accident. Many everyday products contain banned substances-for example, cold remedies, analgesics, hay fever medication, herbal preparations, and nutritional supplements.

Over the years there have been several high profile cases of sportspeople who, having been found to commit a doping offence, argue that it was inadvertent. In some of these cases, the subsequent disciplinary committee hearing has agreed that the cause of the offence was an accident. $^{3}{ }^{4}$

These cases highlight the problem faced by sportspeople in preventing inadvertent doping offences. Products may have compositions that differ depending on the country of origin, or which change without warning. ${ }^{5}{ }^{6}$ The labelling is often incomplete, ${ }^{56}$ written in a foreign language, and may be too complex for a non-specialist to understand. Increasing numbers of sportspeople train and compete abroad, and it may be difficult for them to easily access advice about a substance they wish to take. There may also be person specific errors such as ignorance, naivety, and failure to check thoroughly. This study was designed to look at sportspeoples' perception of the problem, to assess their educational needs, and to find ways of reducing the likelihood of them taking banned substances by accident.

\section{METHODS}

\section{Participants and design}

The study was carried out as a cross sectional survey in 2003. A total of 196 sportspeople were mailed a questionnaire asking about issues relating to doping in sport. After discussion with the British Olympic Association (BOA), it was decided to send the questionnaire to people participating in sports on the "Priority One" list; these are the sports assessed as having the best prospects of a medal at the Olympic Games. The sports were athletics, cycling, rowing, and sailing.

As this was designed as an exploratory study, no formal sample size/power calculation was carried out a priori; no specific hypothesis was being investigated. The Central Office for Research Ethics Committees and the North Staffordshire Local Medical Ethics Committee both reviewed the project and judged that formal ethical approval and consent from the subjects was not necessary on the basis of its design and exploratory nature.

\section{Questionnaire}

The questionnaire was carefully constructed using principles outlined in a number of publications. ${ }^{7-9}$ A literature search for doping issues in sport was used to construct the questionnaire. The questions are listed below.

- Questions 1-2 concerned the date and source of the last doping educational update respectively.

- Question 3 instructed the subjects to rate five statements using a seven point ordinal scale ranging from 1 (strongly disagree) to 7 (strongly agree):

- "I have received the information I need to avoid getting into trouble with the doping laws" 
- "I should receive reminders more often"

- "I don't know how to check if something is banned"

- "The authorities should do more to educate sportspeople"

- "Keeping up to date with the doping laws is the responsibility of the sportsperson, not the authorities".

- Questions 4-5 were open questions ascertaining what strategies the subjects would use to check the legality of a substance, separately in the United Kingdom and when abroad.

- Question 6 was an open question that invited suggestions from the subjects as to how to improve the current doping education programme.

- Question 7 asked if the subject had ever taken a banned substance by accident (yes/no).

- Question 8 was an open question that sought the subject's opinion as to why sportspeople might accidentally take a banned substance.

- Question 9 instructed the subject to list as many as possible everyday products that might contain banned substances.

- Questions 10-13 concerned age, sex, sport, and years at national sporting level.

- Question 14 asked the subject if they were a sports supplement user (yes/no).

\section{Survey administration}

An introductory letter, a questionnaire, and a stamped addressed return envelope were included in each survey pack. The packs were sent to the BOA, who addressed and posted them. In this way the researcher was blinded as to the identity of the people to whom the pack was sent. The questionnaires and return envelopes also had no identifying marks on them, ensuring anonymity for the respondents.

Follow up of non-responders has been shown to improve response rate to postal questionnaire surveys. ${ }^{10}$ However, advice was received that doping is a sensitive subject for sportspeople, and any attempt to identify non-responders, even if blinded from the researcher, would probably result in a very poor response rate. It was decided that it was more important to be able to reassure the sportspeople of absolute

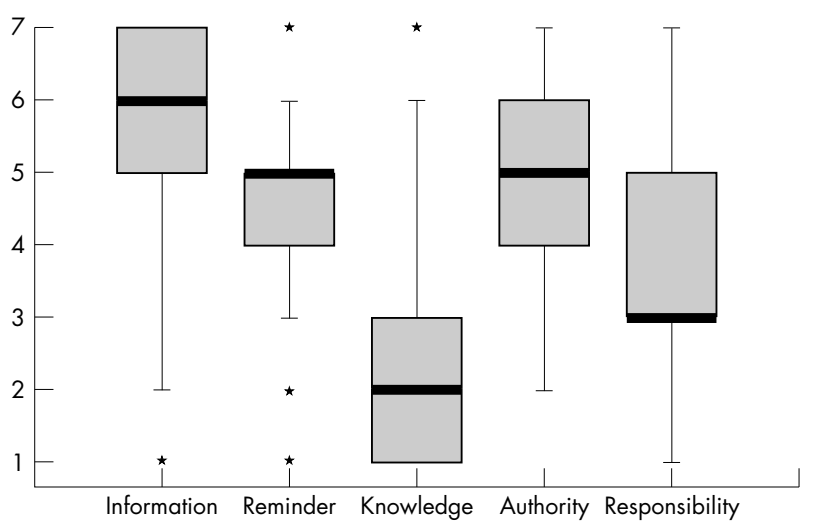

Figure 1 Box plot summarising the responses to the five items on perceived education received. Scores on scale 1-7: 1 = strongly disagree; 4 = neither agree nor disagree; $7=$ strongly agree. Information = "I have received the information I need to avoid getting into trouble with the doping laws"; Reminder = "I should receive reminders more often"; Knowledge = "I don't know how to check if something is banned"; Authority = "The authorities should do more to educate sports people"; Responsibility = "Keeping up to date with the doping laws is the responsibility of the sportsperson, not the authorities". The asterisks represent outlying observations, defined as values that lie more than 1.5 box lengths above or below the box. anonymity, and therefore no methods were used to identify non-responders.

\section{Statistical methods}

Replies were entered on a Microsoft Access database and then analysed using SPSS for Windows version 11. Firstly, the data were summarised using descriptive statistics. Secondly, associations within the dataset were explored using non-parametric methods including Spearman's $\rho$ correlation, and $\chi^{2}$, Mann-Whitney $U$, and Kruskal-Wallis tests of statistical significance, as appropriate. Analyses were also carried out with respect to subgroups of age, sex, sport, and years at national level. Stratifications for age and number of years at national level were derived using the median value as the cut off for categorisation. For all statistical tests, a significance level of $5 \%(\alpha<0.05$, two tails $)$ was defined, as traditionally accepted. Non-parametric methods were used because of the non-numerical content of the measures being analysed and size of the study.

\section{RESULTS}

\section{Survey response}

Seventy four $(38 \%)$ replies were received. Twenty nine respondents were involved in athletics, seven in cycling, 25 in rowing, and 11 in sailing (two questionnaires not completed). The sex breakdown was 40 men and 33 women (one not completed). The median age was 27 years (range 20-37), and the median time as a national level performer was 7 years (range 2-23).

The BOA had records of the sex of all 196 sportspeople sent questionnaires, but only had age recorded for 20 . The study population (196) included 132 men (67\%) and 64 women $(33 \%)$. Thus there were two possible permutations of response to non-response sex distributions (M/F): (a) 41/33 for responders and 91/31 for non-responders; (b) 40/34 for responders and $92 / 30$ for non-responders. In each case, more women than men replied to the questionnaire $\left(\chi^{2}\right.$ test, $\left.\mathrm{p}<0.01\right)$.

\section{Date and source of last doping educational update}

Of the 65 respondents who completed the date of the last doping educational update, $60(92 \%)$ had received an update in the last six months, three had done so 7-12 months previously, one was 13-24 months previously, and one responder reported last receiving an update more than 24 months previously. Identified sources were the national governing body ( $\mathrm{n}=47,65 \%)$, BOA $(\mathrm{n}=7,10 \%)$, UK Sport $(\mathrm{n}=14,19 \%)$, Doping Control $(\mathrm{n}=2,3 \%)$, and other sporting bodies $(\mathrm{n}=3,4 \%)$.

\section{Perception of education received}

Figure l summarises the response to the five individual items listed in question 3. Respondents were largely in agreement with the statements: "I have received the information I need to avoid getting into trouble ...", "I should receive reminders more often" and "The authorities should do more ...". Conversely, the respondents were more likely to be in disagreement with the statements: "I don't know how to check if something is banned" and "Keeping up to date ... is the responsibility of the sports person, not the authorities". For each of the five individual items, there were no significant differences in scores between sexes, age categories $(<27$ years, $\geqslant 27$ years $)$, and years at national level ( $<7$ years, $\geqslant 7$ years) using the Mann-Whitney $U$ test $(p>0.05$ in each case). In terms of between-sport differences, responses to item 1 (received adequate information) were quite different, with athletes (median 5, range 1-7) and sailors (median 5, range 2-7) scoring lower on average than cyclists (median 7 , range 5-7) and rowers (median 7, range 5-7). This difference was not significant (Kruskal-Wallis test, $p=0.067$ ). All 
Table 1 Sources of doping information that sportspeople would use when in the United Kingdom and overseas (\% of respondents)

\begin{tabular}{|c|c|c|c|c|c|c|}
\hline & $\begin{array}{l}\text { Contact } \\
\text { team doctor }\end{array}$ & $\begin{array}{l}\text { Consult C\&O } \\
\text { guide* }^{*}\end{array}$ & $\begin{array}{l}\text { Consult other } \\
\text { written } \\
\text { information }\end{array}$ & $\begin{array}{l}\text { Telephone } \\
\text { a sporting } \\
\text { body }\end{array}$ & $\begin{array}{l}\text { Use UKS } \\
\text { website† }\end{array}$ & Otherł \\
\hline \multicolumn{7}{|c|}{ United Kingdom } \\
\hline Athletics & 31 & 24 & 7 & 72 & 17 & 3 \\
\hline Cycling & 86 & 14 & 29 & 0 & 0 & 0 \\
\hline Rowing & 92 & 20 & 4 & 24 & 36 & 4 \\
\hline Sailing & 73 & 27 & 0 & 9 & 45 & 0 \\
\hline All sports & 62 & 22 & 7 & 38 & 26 & 3 \\
\hline \multicolumn{7}{|l|}{ Overseas } \\
\hline Athletics & 34 & 7 & 3 & 52 & 7 & 0 \\
\hline Cycling & 100 & 14 & 43 & 0 & 0 & 0 \\
\hline Rowing & 100 & 0 & 8 & 8 & 0 & 0 \\
\hline Sailing & 64 & 18 & 0 & 9 & 36 & 9 \\
\hline All sports & 66 & 7 & 8 & 24 & 8 & 1 \\
\hline \multicolumn{7}{|c|}{$\begin{array}{l}\text { Respondents were able to state more than one source. } \\
\text { *Competitors and Officials Guide to Drugs and Sport. } \\
\text { †UK Sport Drug Information Database website. } \\
\text { †One athlete and one rower both stated they would ask a training partner, and one sailor stated that he would ask } \\
\text { a physiotherapist. }\end{array}$} \\
\hline
\end{tabular}

other items were similarly scored across responders in the four different sports.

A correlation matrix was derived to determine the bivariate associations between the five items for perception of education received. There were four significant correlations. Firstly, those stating that they have received adequate information were more likely to state that they did not want reminders more often $\left(r_{s}=-0.29, \mathrm{p}=0.011\right)$. Secondly, those stating that they had received adequate information were more likely to state that they knew how to check a substance against the doping laws $\left(r_{s}=-0.51, \mathrm{p}<0.001\right)$. Thirdly, those stating that they wanted reminders more often were more likely to state that the authorities should do more $\left(r_{s}=0.37, \mathrm{p}=0.001\right)$. Fourthly, those stating that the authorities should do more were more likely to state that the athlete was responsible for keeping up to date with the doping laws $\left(r_{s}=0.30, \mathrm{p}=0.009\right)$.

\section{Checking a substance}

Table 1 summarises responses to the questions asking respondents how they might check that a substance is legal for them to ingest, when in the United Kingdom and abroad.

Table 2 Suggestions from elite sportspeople to improve the education that they receive, to prevent inadvertent breaches of the doping regulations

\begin{tabular}{ll}
\hline Suggestion & $\begin{array}{l}\text { Number of } \\
\text { respondents } \\
\text { expressing } \\
\text { suggestion }\end{array}$ \\
\hline Increase awareness of UK Sport Website & 13 \\
Regularly updated list of acceptable supplements \& & \\
medicines & 13 \\
24 hour telephone help line & 9 \\
Improve labelling & 7 \\
UK Sport manufacture/brand own supplements & 3 \\
Mobile phone text reply service & 2 \\
Make UK Sport website easier to use & 2 \\
Take nothing unless doctor approves it & 2 \\
Wider distribution of Competitors \& Officials Guide & 1 \\
Easier access to medical staff & 1 \\
Better advice to general practitioners & 1 \\
Annual update to Competitors \& Officials Guide & 1 \\
Medical packs with simple remedies & 1 \\
Foreign drugs included on website & 1 \\
Pharmacists given information & 1 \\
Reinforce message to always check with doctor & 1 \\
Check list for support staff & 1 \\
\hline
\end{tabular}

Most respondents stated that they would contact the team doctor whether they were in the United Kingdom or overseas.

\section{Suggestions for improving education}

Responses were grouped into themes, and table 2 shows the frequency of response to these themes. The two most common themes reported were the suggestions to "increase awareness of the UK Sport website, and "provide regular updated list of acceptable supplements and medicines".

\section{Accidental doping breaches}

One of 29 athletes and three of 11 sailors admitted that they had accidentally ingested a banned substance in the past. Analysis of these respondents showed that they were more likely to have served a longer time at national level (MannWhitney U test, $\mathrm{p}=0.022$ ) and were less likely to agree with the statement "Keeping up to date ... is the responsibility of the sports person, not the authorities" (Mann-Whitney U test, $\mathrm{p}=0.015$ ).

Table 3 Reasons given by elite sportspeople as to why accidental breaches of the doping regulations might occur

\begin{tabular}{ll}
\hline Reason for accidental doping breach & $\begin{array}{l}\text { Number of } \\
\text { respondents } \\
\text { expressing } \\
\text { suggestion }\end{array}$ \\
\hline Inadequate labelling/changes in product composition & 16 \\
Lack of knowledge & 16 \\
Human error/forgetfulness/learning difficulties & 13 \\
Laziness/failure to read advice/failure to check substance & 12 \\
Different composition of drugs in other countries & 8 \\
Naivety/risk taking & 4 \\
General practitioner error & 3 \\
Team doctor error & 3 \\
New to elite sport/inadequate advice at junior level & 2 \\
Don't want to make a fuss over a simple OTC remedy & 2 \\
Athlete belief that minor illness needs OTC medication & 2 \\
Very complicated issue & 2 \\
Keen to get better and return to training & 2 \\
"Set ups" & 1 \\
Inability to quickly access team doctor & 1 \\
Coach error & 1 \\
Excuse for deliberate cheating & 1 \\
Changes in regulations & 1 \\
Underperforming because of illness will make & \\
testing less likely & 1 \\
Too ill to realise to check list & 1 \\
\hline OTC, Over the counter. & \\
\hline
\end{tabular}


Table 4 Number of responders taking supplements stratified by sport, age, sex, and years at national sport level

\begin{tabular}{|c|c|c|c|}
\hline & $\begin{array}{l}\text { Supplement } \\
\text { use }\end{array}$ & $\begin{array}{l}\text { No } \\
\text { supplements }\end{array}$ & Total \\
\hline All responders & $41(55)$ & $33(45)$ & 74 \\
\hline \multicolumn{4}{|l|}{ Sport } \\
\hline Athletics & $16(55)$ & $13(45)$ & 29 \\
\hline Cycling & $6(86)$ & $1(14)$ & 7 \\
\hline Rowing & $9(36)$ & $16(64)$ & 25 \\
\hline Sailing & 8 (73) & $3(27)$ & 11 \\
\hline \multicolumn{4}{|l|}{ Age } \\
\hline$<27$ years & $15(44)$ & $19(56)$ & 34 \\
\hline$\geqslant 27$ years & $26(65)$ & $14(35)$ & 40 \\
\hline \multicolumn{4}{|l|}{ Sex } \\
\hline Female & $21(64)$ & $12(36)$ & 33 \\
\hline Male & $20(50)$ & $20(50)$ & 40 \\
\hline \multicolumn{4}{|l|}{ National level } \\
\hline$<7$ years & $18(50)$ & $18(50)$ & 36 \\
\hline$\geqslant 7$ years & $23(62)$ & $14(38)$ & 37 \\
\hline
\end{tabular}

\section{Everyday products that might contain a banned substance}

The median number of responses to this question was 2 (range $0-7)$. Five $(7 \%)$ respondents did not list any products, 21 listed one product, 18 listed two products, 18 listed three products, and 12 listed between four and seven products. The most commonly listed products were cold remedies, nutritional supplements, and analgesics.

\section{Reasons for accidental breaches}

Table 3 lists the replies, and frequencies of response are summarised. The two most common responses were "inadequate labelling and changes in product composition", and "lack of knowledge".

\section{Supplement usage}

Forty one $(55 \%)$ responders reported taking supplements. Table 4 shows the number and percentage taking supplements within each sport and stratified by subgroups of age, sex, and number of years at national sporting level. There was a difference in the proportions of responders taking supplements between sports: cyclists were more likely to be taking supplements (no formal statistical test could be carried out because of low cell expected frequency counts). Supplement use was greater among older athletes and women, although these results were not significant: age (Mann-Whitney U test, $p=0.245)$ and $\operatorname{sex}\left(\chi^{2}\right.$ test, $\left.p=0.243\right)$. However, there was statistical evidence that responders who reported taking supplements were more likely to have spent a longer time at national level than those who were not supplement users (median time $8 v 6$ years for users and non-users respectively; Mann-Whitney U test, $\mathrm{p}=0.031$ ).

\section{DISCUSSION}

Nearly all of the sportspeople reported that they had received an update within the last six months, which is encouraging. Most seemed happy with the information that they had received, particularly the cyclists and rowers, and felt they knew how to check on a substance before taking it. There was a preference for more frequent reminders, and a feeling that the authorities should do more to educate sportspeople and shoulder more of the burden of responsibility for keeping up to date with the doping laws. A large number were actively taking supplements, and four had taken banned products by accident. There appeared to be a lack of knowledge on banned substances, but there was good feedback relating to ways of improving this knowledge within the sporting community.
The questionnaire sought to test the knowledge of the sportspeople: one question asked them to suggest as many everyday products as possible that might contain banned substances. It is a little disappointing, given that there are hundreds of possible answers, that the average number of suggestions was about two. In addition, although not reaching statistical significance, $56 \%$ of supplement users failed to indicate supplements as a possible source of banned substances. Both of these findings may indicate that the respondents are less well equipped to avoid accidental doping infringements than they believe themselves to be.

The team doctor was by far the most common source of information suggested by respondents for checking a substance. However, the doctor may not always be accessible, especially when abroad. There are also no published studies that assess the competence of team doctors with doping issues. One of those who admitted an accidental breach in this study alleged that the team doctor had given him a drug containing a banned substance. It would therefore seem sensible that team doctors receive regular updates and are assessed on their knowledge of doping issues.

Some of the respondents suggested a 24 hour telephone help line, as they had found at times that they had been unable to access telephone advice from sporting bodies such as their national governing body. Many countries, including Britain, Norway, and the Netherlands, operate a help line during daytime working hours. However, 24 hour coverage is unlikely to be feasible because of cost. An alternative could be to use the internet and email to provide up to date information. For example, the UK Sport Drug Information Database (http://www.uksport.gov.uk/did/) ${ }^{12}$ is a good source of regularly updated information, and it is perhaps surprising that it is used so little. Only $8 \%$ of sportspeople suggested using it when abroad. This may be due to problems with access to the internet, as not all countries have widespread public access. This may be an area for development, with governing bodies pushing for better internet access at training and competition venues abroad.

Sixteen respondents suggested that a national sports body, such as UK Sport or the BOA, manufacture, brand, or endorse legal supplements and drugs. There is certainly evidence that contamination of supplements is commonplace. For example, a spate of recent doping violations amongst tennis players on the ATP tour have been attributed to supplements given to the players by trainers employed by the ATP, unaware that they contained nandrolone. ${ }^{15}$ An IOC commissioned study examined 634 non-hormonal nutritional supplements purchased from shops, by post, and via the internet. Overall 15\% contained pro-hormones of testosterone or nandrolone. ${ }^{16}$

Continuing with this theme, inadequate labelling and variations in constituents in different products were identified by about a third of respondents as a reason for accidentally consuming a banned substance. Suggestions were made that an "athlete safe" logo be used to show that a product is safe to take, and indeed this already happens in the Netherlands. In Germany one manufacturer produces supplements for the national teams. Both of these strategies are useful steps forward if quality control during manufacture is sufficient to prevent unexpected contamination, as sometimes has happened with the food industry in relation to nut allergy. For this reason some British sports obtain supplies of supplements from a trusted supplier, but also have them individually tested at WADA approved laboratories.

Another solution already used is to have a pharmacy and pharmacist attached to the medical centre at large sports events-for example, The Commonwealth Games, Manchester, UK, 2002. Sportspeople can then obtain any recommended drug with confidence. National sporting bodies may wish to consider developing a similar nationwide 


\section{What is already known on the topic}

There have been many cases of breaches of the doping laws by sportspeople caused by accidental ingestion of banned substances. Despite this, there are no published studies that look at the sportsperson's perception of the problem, their educational needs, and ways of preventing such errors.

network of "approved sports pharmacists" for use outside of competition, both in the United Kingdom and abroad.

Four out of 74 respondents admitted that they had accidentally taken a substance containing a banned substance, with no intention of cheating. One respondent explained that he had developed an upper respiratory tract infection during an important training camp, and took a pseudoephedrine-containing cold remedy without thinking. Another blamed the belief of some sportspeople of the need to medicate during any illness. These examples suggest that education about the management of minor illnesses may be required, alongside the information about banned substances. UK Sport does produce an advice card with suggested permitted remedies for common minor illnesses.[17] It would also make sense for sportspeople going to training camps to bring a supply of any regular medication with them, but also to anticipate minor illnesses occurring and to bring an "approved sports first aid kit" with them. This would reduce the likelihood of the sportsperson making the wrong choice of medication while under the pressure of training and while feeling ill.

The other commonly stated reason for an accidental doping breach was some form of human error. This encompasses lack of knowledge, learning difficulties, naivety, laziness, forgetfulness, and focus on training/competing. Several respondents stated that they had not considered what they would do when they were abroad. Improvements to the doping education programme could include producing a contingency plan for minor illness, tailored to each sportsperson's own medical needs, as part of their regular doping educational update.

The $38 \%$ response rate compares with an average of $47 \%$ from the meta-analysis of 93 questionnaire studies. ${ }^{13}$ There are a number of possible reasons for this low response rate. Doping is a sensitive issue for sportspeople and many may have been reluctant to participate. It is also difficult to choose the best time to send out the questionnaire as many sportspeople train and compete abroad for a large proportion of the year. Assured anonymity took precedence over increased response: a second mailing was not carried out on this basis. This meant a possible trade off between a potential reduction in information bias and increase in selection bias of study participants. One further limitation is the size of the study, which would have an effect on statistical power and therefore the subsequent interpretation of any statistical associations that had been investigated.

\section{CONCLUSION}

This survey suggests that despite regular educational updates, some sportspeople are not fully prepared to avoid accidental doping violations. It is suggested that the educational process itself is altered to encourage a more proactive approach to doping prevention, with the development of individual contingency plans should minor illness arise. Improving access to information via the internet, and involving a pharmacist may help to reduce doping accidents. There is also a need to consider the educational requirements of team doctors.
What this study adds

- Sportspeople wish to have access to supplements and medicinal products that are clearly labelled as being safe for them to take.

- There is a need to improve access to information for sportspeople, on a 24 hour, worldwide basis.

- Doping education should include contingency planning for minor illness.

\section{ACKNOWLEDGEMENTS}

We thank the British Olympic Association, Dr Rod Jaques, Dr Ben Crystall, Professor Peter Croft, Dinah Derby, Emily Brown, and Jabeen Khan for their support of this project. This survey would not have been possible without the participation of the sportspeople themselves, who generously spared time to take part.

\section{Authors' affiliations}

S J Somerville, The John Kelso Practice, Leek, Staffordshire, UK M Lewis, Primary Care Sciences Research Centre, Keele University, Keele, Stoke on Trent, Staffordshire, UK

Competing interests: none declared

\section{REFERENCES}

1 World Anti-Doping Agency. The World Anti-doping Code. 2003. http:// multimedia.olympic.org/pdf/en_report_818.pdf (accessed 22 Jul 2004).

2 World Anti-Doping Agency. The 2004 Prohibited List, International Standard. Update 17 Mar 2004. http://www.wada-ama.org/docs/web/standards_ harmonisation/code/list_standard_2004.pdf (accessed 22 Jul 2004).

3 Court of Arbitration for Sport. Baxter v IOC (2002) (CAS 2002/A/376). http://www.tas-cas.org/en/pdf/juris5.pdf (accessed 7 Aug 2003)

4 Court of Arbitration for Sport. Raducan v IOC (2000) (CAS OG00/011). http://www.tas-cas.org/ (accessed 7 Aug 2003).

5 Green GA, Catlin DH, Starcevic B. Analysis of over-the-counter dietary supplements. Clin J Sport Med 2001:11:254-9.

6 Kamber M, Baume N, Saugy M, et al. Nutritional supplements as a source for positive doping cases? Int J Sport Nutr Exerc Metab 2001;11:258-36.

7 Leung WC. How to conduct a survey. Student BMJ 2001;9:143-5.

8 Leung WC. How to design a questionnaire. 2001. hitp://www. studentbmj. com/back_issues/0601/education/187.html (accessed 1 Oct 2002).

9 Sims J, Wright C. Research in health care: concepts, designs and methods. London: Nelson Thornes, 2000.

10 Edwards P, Roberts I, Clarke M, et al. Increasing response rates to postal questionnaires: systematic review. BMJ 2002;324:1183-5.

11 United Kingdom Sports Council. Competitors and officials guide to drugs and sport. London: United Kingdom Sports Council, 1998.

12 UK Sport. UK Sport Drug Information Database. http://www.uksport.gov.uk/ $\mathrm{did} /$ (accessed 30 Oct 2003).

13 Yu J, Cooper H. A quantitative review of research design effects on response rates to questionnaires. Journal of Marketing Research 1983;20:36-44.

14 ATP. ATP expands its efforts to determine cause of low-level nandrolone in test results. 10 Mar 2004. http://www.atptennis.com/en/common/Tracklt. asp?file =/en/antidoping/nadrolone_release.pdf (accessed 1 Apr 2004).

15 Schänzer W. Analysis of non-hormonal nutritional supplements for anabolicandrogenic steroids: an international study. 2003. http:// multimedia.olympic.org/pdf/en_report_324.pdf (accessed 24 Oct 2004).

16 UK Sport. Anti-Doping Directorate advice card. London: UK Sport, 2001.

\section{COMMENTARY}

Generally it is overlooked that part of the doping problem stems from inadequate information and education. However, few data on this assumption have been published. Although the study has a relatively simple design, this paper presents valuable data, indicating that education should be an integral part in the fight against doping in sport.

H Kuipers

Department of Movement Sciences, University of Maastricht, Maastricht, the Netherlands; harm.kuipers@bw.unimaas.nl 